\title{
Impact of Taxes and Agency Costs on Dividend Policy
}

\author{
Pavel Kraus*
}

\section{Introduction}

Recent financial research has been trying to explain dividend decisions and its impact on values of shares. There have been two contradictions which must be analyzed in detail.

First, companies pay out dividends and raise external capital (debts, shares) to finance investments incurring additional transactional costs. We may assume that dividend policies are influenced by imperfect information in real estate market, resulting monitoring problems and agency costs. The reason is that changes in market values and cash flows are really very complicated to be estimated.

Second, companies continue paying out large portions of its income by means of dividends even if dividends are often subject to higher tax rates and dividend income must be taxed by shareholders immediately.

The first part of this article analyzes determinants of dividend policy, aimeding especially at agency costs. In the second part, methods for avoiding taxes on distributed dividends will be explained and analyzed.

\section{Imperfect information and its impact on dividend policies}

A basic question has been why companies pay out dividends and simultaneously raise external capital for covering of its investments incurring substantial costs of issuing new securities.

This question can be analyzed on real estate investment trusts (REIT) in USA because they have been forced to pay out substantial part of their income $(95 \%)$ as dividends. In fact, REIT has been paying out more than the required limit 95\%. Furthermore, authors consider two different types of REIT's. Mortgage REIT investing funds in mortgages securities with mostly fixed coupon payments represents easier predictable future cash flow and risk for its shareholders than in case of equity REIT's investing their funds directly in shares of other firms.

\# This article, which has been elaborated as one of the outcomes of research project registered with the Grant Agency of the Czech Republic under reg. no. 402/04/1313.

* Ing. Pavel Kraus - Ph.D. student; Department of Corporate Finance and Valuation, Faculty of Finance and Accounting,. University of Economics, Prague, nám. W. Churchilla 4, 13067 Prague 3, Czech Republic; $<$ kraus@vse.cz>. 


\subsection{Resources for exceeds of the $95 \%$ - limit}

REIT's are able to exceed the limits set for dividend ratio by tax law because their annual cash flow is higher than their tax - qualifying income. Two main sources of prevalence of annual cash flow over taxable income might be identified:

- Accrued revenue and expenses

- Building depreciation

\subsection{Possible non-tax determinants of dividend policy}

We may assume that dividend policies are mostly influenced by imperfect information in real estate market and resulting agency costs because changes in market values and cash flows are really very complicated to be estimated. Therefore, investors of REIT may have a problem to monitor management decisions. As a result, many shareholders may prevent uneconomical management's investments by paying out all available resources as dividends. Thus, it would be more likely that the company must raise external financing in financial markets where monitoring costs may be less costly.

Following potential determinants might be considered:

- Type of investment fund:

The unique characteristics of REIT might help us to define two types of investment corporations based on predictability of future cash flow from investments. On one hand, investment funds investing in mortgage certificates may have better projected cash flows due to fix coupon payments and required rate of return which might be easier to estimate. On the other hand, future cash flows of investment funds investing directly in equity are based on rents, expenses and appreciations which are very hard to be estimated without a detailed investigation and analysis. Thus, monitoring costs of those funds will be higher and shareholders will tend to have higher payout ratios.

- Availability of historical performance

We also suppose the dependence of dividend policy on length and quality of company's historical performances. If the company has a good record, there is less need for internal monitoring of managers. Performance of the whole company can be measured by return on assets (ROA). Calculation of ROA is based on booking values of assets, so market changes of asset prices aren't taken into account in this ratio. Thus, authors choose Tobin's $\mathrm{Q}$ to estimate performance. This ratio measures market value of debt and equity to the replacement costs of assets. Litzenberger and Lang (1989) use this ratio to identify overinvested companies. If this ratio is less than one, they suggest that company overinvests in projects with negative net present value. Moreover, we might hypothesize negative relationship between Tobin's $\mathrm{Q}$ and dividend payout ratio. The hypothesis suggests that in there are higher risks of agency costs in an overinvesting company, so shareholders prefer to pay out the most of the company's income as dividends. 
- Growth of assets

The higher volume of assets a company has, the less it should pay out as dividends in order to have enough sources to finance the assets. Otherwise, it would be forced to raise external capital for its investments. Thus, we might suppose relationship between growth of assets and dividend payout ratio. This hypothesis has been confirmed by Rozeff's analysis (1982) of a sample of 1000 companies showing negative connection of dividend policy to growth of assets.

- Size of debts

We can measure the size of debts as a ratio of debts to assets. By using higher level of debts, company might have more resources to pay out dividends. Thus, we suppose a positive relation between debt to asset ratio and dividend payout ratio.

To sum, authors use a following model to test non-tax determinants of REIT payout ratio. Moreover, expected signs of each independent variable are brought in parentheses.

$$
P A Y O U T=f(T Y P E, R O A, Q, G R O W T H, D E B T)
$$

$(-) \quad(-) \quad(-) \quad(-) \quad(-)$

\subsection{Sample selection}

Wang, Erickson and Gau (1993) selected 123 trusts that are listed in National Association of Real Estate Investment Trusts (NAREIT) and have annual dividend and income information on Compustat Industrial Annual files. Furthermore, 123 trusts were separated into equity, hybrid and mortgage type of investment trusts according to their asset data. All hybrid trusts (21) were excluded from analysis to ensure a clear difference between mortgage and equity REIT. Authors collected dividend data of years $1981-1988$ for all 102 equity and mortgage trusts. However, many trusts had missing information, so they reduced the analysis only to years $1985-1988$.

\subsection{Empirical results}

The results generally support the impact of agency costs on dividend policy.

The coefficients for type of REIT had the expected signs. Coefficients for three of the four years have proved being significant for explanation of dividend policy. Furthermore, management performance can be explained by ROA according to level of significance being achieved in all four years. This result strongly supports the hypothesis that management decisions in a company with very good performances do not need to be monitored as closely as in case of newer companies. Companies with shorter history will be forced to pay out as much as possible so that management decisions can be monitored by external markets.

On the contrary, Tobin's Q does not seem to be good explanation for the dividend policy. Only two of four coefficients had the expected sign and none of them was statistically significant. Asset growth achieves the expected sign in all four years. However, only one coefficient proved to be significant. It means quite a weak support for hypothesis that REIT with greater asset growth tend to retain more income in order to prevent the company from raising funds in external markets. Finally, three of four coefficients of debt-to-asset ratio had expected sign (two of them were statistically significant). 


\section{Possibilities for avoidance of dividends taxing}

We will consider one unlevered firm owning all corporate capital of our hypothetical economy. At the beginning of a period the company has an amount of earnings $\left(X_{\mathrm{t}}\right)$, which can be paid out as dividends $(D)$ or can be invested in productive assets $(I)$. In next period the company might generate resources of $X_{t+1}$ (thanks to investments in productive assets in previous years), which can be either paid out or retained for other investments. However, we are not allowed to forget the back purchase of shares as a possible alternative approach to distribute earnings to shareholders. Our hypothetical company does not posses any debts. In addition to retained earnings, the company might raise its funds by issuing new shares. Investors who finance their investments by using equity as well as debt sources own shares of the company. The risk free rate of interest $(r)$ will equilibrate the demand and supply of bonds among investors. Our investor is additionally allowed to invest in insurance policies. Insurance companies are allowed to hold only risk free debt securities. Finally, our investor may invest into building's savings. Interests of building's savings are very similar to exercise of rights from insurance policies because both are exempt.

Moreover, we assume a tax system where financial expenses can be deducted maximally up to the corresponding financial income. Based on assumptions above we can establish a proposition about independency of shareholder's wealth on dividend policy. We might analyze effects of a change in dividend policy on shareholder's wealth.

In case of a highly levered investor where financial expenses already exceed the financial income, additional dividends only generate possibility of further deductions of expenses. Obviously, this change in dividend policy will have no effect on shareholder's tax duty.

Let's assume an investor whose financial expenditures equal financial income. If such a investor did not react on dividend increase, his tax liability would rise. However, we can borrow additional loan. Interests of this loan would fully offset the increase in financial income (dividend increase). Furthermore, additional funds from loan can be invested in insurance policy (exercise of rights to cash or to retirement annuity are exempt), which keeps the risk of the portfolio at the same level no matter how big our debts are. Additionally, funds borrowed to offset the dividend increase can be deposited on accounts with building societies. The interests resulting from such accounts are tax-exempt.

Finally, we shall consider situations of dividend reduction. The dividend reduction can cause an excess of expenses over dividends to emerge or to increase. The reduction will have no negative effect on shareholder's tax liability.

We can make a conclusion that neither dividend reductions nor dividend increases have any effect on wealth of shareholder despite the differences in tax burden of dividends and capital gains.

\subsection{Investor's leverage and decision between dividends and capital gains}

In this part, I want to show the possibility of transformation of dividends into capital gains. We consider an investor with a net worth of 25000 EUR invested in 2500 shares per each share purchased for 10 EUR. The total expected rate of return of $10 \%$ is split up in 0,4 EUR per share in dividends and 0,6 EUR per share in price appreciation (capital gains). Furthermore, the investor will borrow 50000 EUR at an interest rate of $6 \%$ and invests this proceed in 5000 additional shares of the same stock. 
The investor's opening balance sheet would be:

\begin{tabular}{|c|c|c|c|}
\hline \multicolumn{2}{|l|}{ Assets } & \multicolumn{2}{|c|}{ Net Worth and Liabilities } \\
\hline 7500 shares per 10 EUR & 75000 EUR & Net Worth & 25000 EUR \\
\hline & & Loan & 50000 EUR \\
\hline Total & 75000 EUR & Total & 75000 EUR \\
\hline
\end{tabular}

The assumed balance sheet at the end of year should be like:

\begin{tabular}{lr|lr}
\multicolumn{2}{c|}{ Assets } & \multicolumn{2}{c}{ Net Worth and Liabilities } \\
\hline 7 500 shares per 10,6 EUR & $\mathbf{7 9 5 0 0 ~ E U R ~}$ & Net Worth & $\mathbf{2 9 5 0 0 \text { EUR }}$ \\
0,4 EUR per share & & Loan & $\mathbf{5 0 0 0 0 \text { EUR }}$ \\
in dividends & $\mathbf{3 0 0 0}$ EUR & Loan interest & $\mathbf{3 0 0 0}$ EUR \\
\hline Total & $\mathbf{8 2 ~ 5 0 0 ~ E U R ~}$ & Total & $\mathbf{8 2 5 0 0 \text { EUR }}$
\end{tabular}

Assuming withdrawal of investment positions, the investor's tax return would be like:

\begin{tabular}{lr|lr}
\multicolumn{2}{c|}{ Ordinary Income } & \multicolumn{2}{c}{ Capital Gains } \\
\hline Dividends received & $\mathbf{3 0 0 0}$ EUR & Sale of share 7 500 shares \\
& $(10,60$ EUR per share $)$ & $\mathbf{7 9 5 0 0 \text { EUR }}$ \\
Loan interests & $\mathbf{3 0 0 0}$ EUR & Original basis & $\mathbf{7 5 0 0 0 \text { EUR }}$ \\
\hline Net ordinary income & $\mathbf{0 ~ E U R ~}$ & Net capital gain & $\mathbf{4 5 0 0 \text { EUR }}$
\end{tabular}

As we can see in table of shareholder's income, the entire return on the shares takes the form of unrealized capital gains in this position.

The after tax income of a levered investor can be expressed as:

$$
Y=g \cdot S+d \cdot(1-t) \cdot S-r \cdot(1-t) \cdot B,
$$

where $g$-capital gain per share in $\%$,

$d$ - dividend per share in $\%$,

$S$ - initial value of shares in EUR,

$t$ - tax rate of dividends,

$r$ - interest rate of loan,

$B$ - initial value of loan.

Furthermore, we must derive three investor's identities:

a) investor's net worth:

$$
W=S-B,
$$

b) before - tax rate of return on the share:

$$
R=d+g,
$$


c) after - tax rate of return on net worth:

$$
y=Y / W
$$

Using all three identities above and formula (1), the after tax - rate of return on net worth can be expressed as:

$$
Y / W \equiv y \equiv r \cdot(1-t)+[R-r+t \cdot(r-d)] \cdot s,
$$

where $\mathrm{s}-S / W$.

A value of $s=0$ signifies a portfolio only in bonds only in bonds with rate of return $r \cdot(1-t)$. A value of $s=1$ implies a portfolio consisting only of stocks on asset side as well as on liability side with rate of return of $g+d(1-t)$. Finally, a value of $s>1$ signifies a levered portfolio.

Considering dividend portion of uncertain total return as given, we might assume a linear relation (for simplicity reasons) between portfolio's risk and value of shares on net worth (leverage). Miller and Scholes uses shares on net worth $s$ as a surrogate for portfolio's risk to be able to analyze the trade - off between expected

\section{Fig. 1: Expected return and portfolio leverage (risk): comparison of taxable and} non - taxable investor

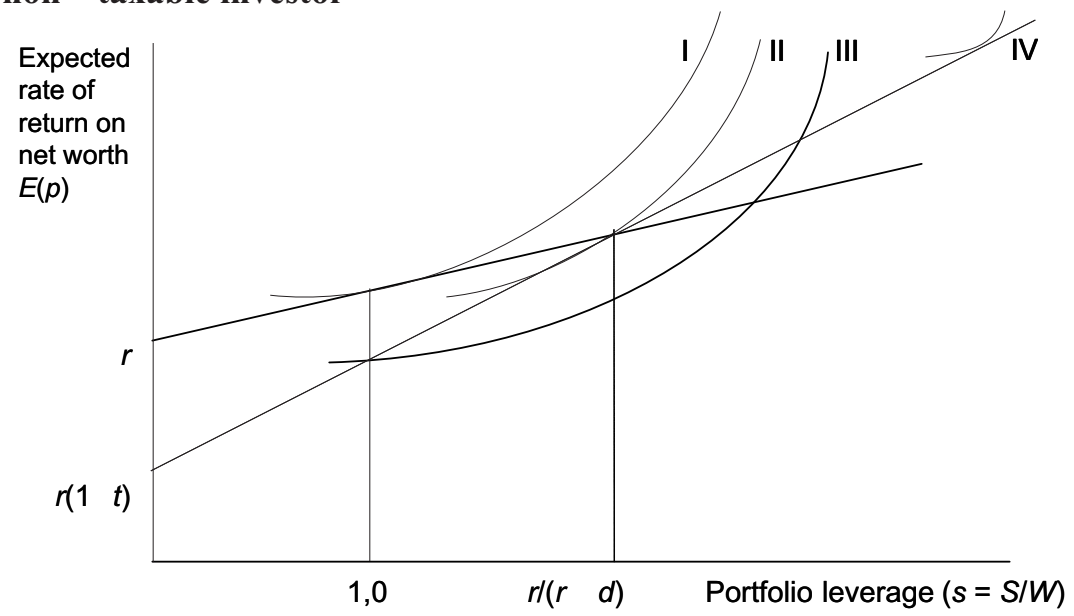

In fig. 1 we draw a linear function expressing relation between expected rate of return and leverage (risk) for taxable and non-taxable investor (return leverage function). Considering taxable and non-taxable investors without leverage, where value of shares equals net worth $(s=1)$. Furthermore, we draw indifference curves I and III crossing the return - leverage functions of taxable and non - taxable investors at a value of $s=1$. The loss of taxable investor is expressed as a vertical difference between indifference curves I and III. By levering the portfolio, the taxable investor can achieve the indifference curve II and thus the welfare loss becomes smaller.

We can imagine situation when dividend's increase does not cause any pressure to raise the the interests to cut back the increased dividend income. Such investors might have high leverage ratios, so their indifference curve might be positioned like indifference curve IV in Fig. 1. Such investor is as unconcerned about division between capital gain and dividends as any other taxpayer with tax-exempt income. 


\subsection{The role of insurance in avoidance of taxation of dividend income}

Life insurance has two main tasks in the model of Miller and Scholes. On the one hand, it serves to control the risk of the portfolio, in particular, to neutralize any added risk resulting from acceptance of loans (leverage) in process of conversion dividends into capital gains. Let's consider the same numerical example from part 3. We suppose an investor who wants to eliminate the tax burden on dividend income and wants to have the same risk level as in original unleavened portfolio. His goal can be achieved by acceptance of a loan of 50000 EUR at an interest rate of $6 \%$.

\begin{tabular}{ll|lr}
\multicolumn{2}{c|}{ Assets } & \multicolumn{2}{c}{ Net Worth and Liabilities } \\
\hline 2500 shares per 10 EUR & $\mathbf{2 5 0 0 0 \text { EUR }}$ & Net Worth & $\mathbf{2 5 0 0 0 \text { EUR }}$ \\
Insurance & $\mathbf{5 0 0 0 0 \text { EUR }}$ & Loan & $\mathbf{5 0 0 0 0 \text { EUR }}$ \\
\hline Total & $\mathbf{7 5 0 0 0 \text { EUR }}$ & Total & $\mathbf{7 5 0 0 0}$ EUR
\end{tabular}

\begin{tabular}{lr|lr}
\multicolumn{1}{c|}{ Ordinary Income } & \multicolumn{2}{c}{ Capital Gains } \\
\hline Dividends received & $\mathbf{1 0 0 0}$ EUR & Sale of share 7 500 shares \\
Insurance & $\mathbf{2 0 0 0}$ EUR & $(10,60$ EUR per share $)$ & $\mathbf{7 9 5 0 0 \text { EUR }}$ \\
Loan interests & $\mathbf{3 0 0 0}$ EUR & Original basis & $\mathbf{7 5 0 0 0}$ EUR \\
\hline Net ordinary income & $\mathbf{0 ~ E U R ~}$ & Net capital gain & $\mathbf{4 5 0 0}$ EUR
\end{tabular}

On the other hand, it provides an opportunity to invest funds at the before tax rate of interests, because earnings related to insurance policies are mostly tax-exempt. Analogically, we assumed the zero tax - rate on capital gains in chapter 3 . At that rate levering by loan and investing in insurance have the same tax consequences like conversion of dividends into capital gains (chapter 3 ). If the tax - rate on capital gains were greater than zero, the mechanism to reduce tax burden could still be used. However, investors might prefer the firm pay out as much of its earnings as they can offset by interests from borrowings. Even though the tax - rate on capital gains were greater than zero, the investors could completely avoid paying taxes from this income by exceeding time - limits between sale and purchase of shares. Of course, it would require very exact record of all shares.

\subsection{Alternative approaches for risk and tax - free accumulation of funds}

Insurance isn't the only existing financial instrument to avoid taxes at the same risk level. One alternative might be pension insurance with deductible contributions. It can look substantially inferior to life insurance, because paid out pension benefits are normally taxable. However, an analysis will show that pension insurance has equivalent wealth consequences to life insurance. Let's consider a simple two periods. The first period will be the earning phase and the second period will be the retirement phase. In the first period, the tax - payer spends $c_{1}$ on consumption during the first phase and places the rest of his after-tax income in life insurance. In the second phase (retirement period), the consumption will be:

$$
c_{2}=\left[w_{1} \cdot(1-t)-c_{1}\right] \cdot(1+r)
$$


where $w_{1}$ - individual income,

$t$ - average income tax rate,

$c_{1}-$ value of consumption in period 1 ,

$r$ - before tax - rate of return.

Now, we can suppose that instead of investing in life insurance, the investor buys pension insurance where contributions are currently deductible. The investor is forced to pay taxes on later pension benefits paid out. Thus, consumption in period 1 would be:

$$
c_{1}=\left(w_{1}-z_{1}\right) \cdot(1-t),
$$

where $z_{1} \quad-\quad$ value of the tax deductible contributions

Consumption in period 2 would be:

$$
c_{2}=z_{1} \cdot(1+r) \cdot(1-t)=\left[w_{1} \cdot(1-t)-c_{1}\right] \cdot(1+r) \text {. }
$$

It is obvious, that values of consumption in period 2 in both cases are the same. In sum, investing after - tax dollars in insurance at the before - rate of interest is equivalent to investment before - tax dollars in pension funds with taxing deferred till withdrawal. This conclusion valid only then if we assume the same personal income tax rates over time.

Considering Czech conditions for investments, I can imagine use of funds from loans in building savings. The building savings have the same characteristics as insurance. The interests on them are tax - exempt as well as this kind of investment is relatively safe. Thus, the building savings can be considered as an alternative approach for risk - and tax - free accumulation of funds.

\section{Conclusions}

Real estate investment trusts (REIT) in USA have been imposed a $95 \%$ required minimum dividend payout ratio. Empirical observations proved that this limit is not sufficient to explain REIT's dividend policies. Most of them pay out more than required by tax law. Authors of empirical research have proven at least partial impact of agency costs on dividend policy. Therefore, shareholders prefer to pay out as much as possible in order to use capital markets for control and monitoring of management investment decisions.

The model of Miller and Scholes has proven that there are possibilities and financial instruments for conversion of dividends into capital gains and, thus, avoidance of dividend taxing. Moreover, by investing the loan funds in life insurance or similar financial instruments, the investor can hold the same risk as in case of unlevered portfolio. However, the model is based on assumptions, which might not be in compliance with provisions of current tax systems in the some countries.

- Offset of dividend income resulting from all shares against interests of loans. In some countries, it might not be possible to use interests of loan, which was financial source only for a portion of shares i the whole portfolio, for elimination of taxable dividend income. The interests would be deductible only proportionally (shares financed by loan / total stock of shares).

- Taxing of life insurance. This assumption does not comply with provisions of Czech law on income tax. On one hand, the tax - payer is allowed to deduct life in- 
surance contributions from taxable income. On the other hand, benefits from life insurance benefits are taxable. We can make a conclusion, that treatment of pension insurance in model of Miller and Scholes is closer to real situation in Czech tax law.

- Tax rate on capital gains. Although the capital gains mostly underlie the lower tax rate than dividends, the assumption of zero rate might not fully comply with the provisions in most tax systems.

\section{References}

[1] MILlER, M. (1977): Debt and Taxes. Journal of Finance, 1978, Vol. 32, No. 2, pp. 261-275.

[2] MILLER, M. - MODIGLIANI, F. (1961): Dividend Policy, Growth and the Valuation of Shares. Journal of Business, Vol. 34, No. 4, pp. 411-433.

[3] MILLER, M. - SCHOLES, M. (1978): Dividend and Taxes. Journal of Financial Economics, 1978, Vol. 32, No. 6. pp. 333-364.

[4] WANG, K. - ERICKSON, J - GAU, G. W. (1993): Dividend Policies and Dividend Announcement Effects for Real Estate Investment Trusts. Urban Economic Association, Vol. 21, No. 2, pp. 185-201. 


\title{
Vliv daní a nákladů zastoupení na dividendovou politiku
}

\section{Pavel Kraus}

\begin{abstract}
Abstrakt
V první části se článek pokouší o vysvětlení dividendové politiky u investičních fondů v USA, které investují v oblasti nemovitostí. Takové typy investičních fondů mají povinnost vyplácet $95 \%$ z čistého zisku v podobě dividend. Empirické studie však ukazují mnohem větší dividendový podíl než činí tento zákonný limit. Jako možné vysvětlení se nabízí vliv nedokonalých informací a nákladů zastoupení. Jsou tedy představeny faktory, které by vliv nákladů zastoupení na dividendovou politiku mohly vysvětlit - typ fondu, ROA, Tobinovo Q, růst aktiv, poměr dluhy/aktiva. Empirické studie provedené autory zdrojového článku dokládají přinejmenším částečný vliv nedokonalých informací a nákladů zastoupení na dividendovou politiku.

V další části se článek zabývá možnostmi, jak se vyhnout zdanění dividend pomocí dluhu a následné konverze dividend do kapitálových výnosů. Dodatečné zdroje získané z dluhu nemusí být investované do akcií, ale mohou být použity na životní pojištění tak, aby byla udržena hladina rizika na stejné úrovni, jako před přijmutím dluhu. Existují však i jiné finanční produkty jako stavební spoření nebo penzijní připojištění, které mohou být také použity za účelem snížení rizika portfolio.
\end{abstract}

Klíčová slova: dividenda; daň; kapitálový zisk.

\section{Impact of Taxes and Agency Costs on Dividend Policy}

\begin{abstract}
Real estate investment trusts (REIT) in USA have been imposed a 95\% required minimum dividend payout ratio. Empirical observations have proved that this limit is not sufficient to explain REIT's dividend policies. Most of them pay out more than required by tax law. Imperfect information and agency costs are hypothesized to be the explanation. Therefore, possible factors for identifying of agency costs are introduced - type of investment fund, ROA, Tobin's Q, asset growth, debt to asset - ratio. Finally, authors of empirical research have proved at least partial impact of agency costs on dividend

This article deals with possibilities of avoidance of tax burden on dividend income by levering of portfolio and conversion of dividends to capital gains. Furthermore, loan funds can be invested in life insurance to hold the risk of portfolio at the level of unlevered portfolio. There are other financial instruments such as building saving or pension insurance, which can be also used to unlever the portfolio.
\end{abstract}

Key words: dividend; tax; capital gain

JEL classification: G30 